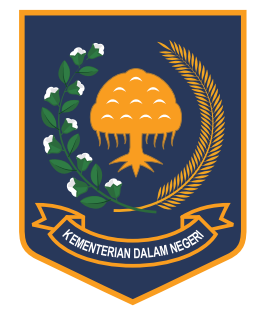

http://jurnal.kemendagri.go.id/index.php/jbp/index

\title{
THE Widespread USE OF Foreign WORD ON ARTIFICIAL ELEMENT TOPOGRAPHICAL NAME in The District AND THE City OF Bogor
}

\author{
Asadi 1, * \\ ${ }^{1}$ Geospatial Training Center-Geospatial Information Agency (BIG) \\ Jl. Raya Jakarta Bogor KM 46 Cibinong-16911
}

Received: 27 June 2016; Accepted: 13 October 2016; Published online: 30 November 2016

DOI: $10.21787 / \mathrm{jbp} .08 .2016 .231-242$

\begin{abstract}
Lately, found many artificial elements topographical names for the names of residents, apartments, and modern markets in a foreign language, especially English. Referring to the legislation governing the use of topographical names, then the provision of topographical names must use Indonesian or local languages. Unfortunately, the obligation to use Indonesian in the provision of topographical names has not been properly socialized and the violation is not accompanied by legal sanctions. This paper examines the issues that are currently going on and developed in society towards topographical naming of artificial elements and the factors that cause the use of foreign names. The method used in this study is a descriptive qualitative method. The result of the study concluded that the English naming for the topographical name of artificial elements due to the influence of globalization, marketing strategy by housing developers, legislation that has not been properly socialized, and the absence of sanctions against violations of the obligation to use Indonesian in the topographical naming of artificial elements. It is expected that this paper can provide awareness to all parties to use Indonesian in the topographical naming of the artificial elements.
\end{abstract}

Keywords: topographical names, residents, modern markets.

\section{INTRODUCTION}

Changes in land use into residential and settlement areas performed by housing developers are always accompanied by the change of topographical names of the land to residential and settlement names. This condition is expected to continue in the coming years because of the increased needs of the community for a place to live. With the ease of buying a home through a bank credit facility and the demand of the people for the housing needs that have comfortable standard and environment with good facilities such as the availability of electricity, drinking water, and other facilities, then the developers of housing are to capture this promising business opportunities by setting up a new residential area. Residential areas liberated by the developers, of course, already have previous topographical names. The change of the designation of land use into new residential areas has an impact on environmental changes, including changes to the social life of the community. One important thing that needs to be underlined is that the topographical names of the areas can be changed in line with the increasing human needs. Each topographical name, both natural elements and man-made elements, needs to be given a permanent name (the official name) by competent authorities.

However, in making land-use change, it must be noted the name of the region that goes with it. The provision of a region name by the developer should pay attention to the rules of naming topographic features as set forth in the legislation. Not only housing developers, government officials related to the licensing and the wider community will still need to pay attention in the provision of man-made topographical names.

At least there are three laws governing the naming of the topographical, namely Law No 24 of 2009 on the Flag, Language, and Symbol of State,

\footnotetext{
* Corresponding Author

Phone : +628128616750

Email : asadi.ibr@gmail.com
} 
as well as Anthem, Presidential Decree No 112 of 2006 on the Committee for Standardization of Topographic Names and the Ministry of Home Affairs Regulation No 39 of 2008 on Guidelines for Standardization of topographical names. Law No 24 of 2009 on the Flag, Language, Flag and Symbol of State, particularly Article 36 paragraph (1), paragraph (2) and (3) which mandates that (1) Indonesian shall be used in the name of geography in Indonesia, (2) the name of the geography as referred to in paragraph (1) has only one official name, and (3) Indonesian shall be used for the name of the buildings, roads, apartments or residential, office, trading complex, trademarks, business institutions, agencies education, organization founded or owned by Indonesian citizens or Indonesian legal entity. Furthermore, in paragraph (4) there is an exception for the use of foreign languages in topographical names if the name has historical values, culture, customs and religion associated with.

Meanwhile, the United Nations (UN) through the United Nations on Geographical Names (UNGEGN) is very concerned about the provision and the standardization of the name of the topographic features, even in some of its resolution ask each country to institute a national authority (National Name Authority) to manage matters related to standardization of topographical names. Based on that UN resolution, then the Government of Indonesia in late 2006 issued Presidential Decree No 112 of 2006 on the National Team for the Standardization of Topographic Names (National Team PNR). Regulation of the Minister of Home Affairs (Permendagri) No 39 of 2008 on Guidelines for the Standardization of Topographic Names is a follow up of the Presidential Decree No 112 of 2006. In the Permendagri described several principles, standardization, procedures, establishment, and standardization of names of topographic features.

In connection with the provision of artificial topographical names, online media 'Kompasiana' (2012) wrote a story about the rise of foreign names provision for the name of housing, giving the impression that the Indonesian is oppressed in its own country. Names such as Village, Residence, Estate, and Park are very commonly found today. In other online news media, reported that the Chinese Government through the Minister of Civil Affairs Li Liguo said that at this time there has been a provision of foreign names for apartments and housing so that it feared would undermine the basic values of socialist and national dignity and sovereignty of the country (http: //www.cnnindonesia.com/ internasional). Furthermore, it is said that the Chinese government will remove all topographical elements names that use foreign names on behalf of housing, apartments, bridges, and other buildings.

Besides vocabulary of topographical names, there is another term with the same meaning, i.e. toponyms, geographical names and place names. In the legislation, the above vocabulary is more popularly known as topographical names. There are at least two Laws that use topographical names for designation of geographical names, namely Law No 24 of 2009 on the Flag, Language, and Symbol of State and Law No 4 of 2011 on Geospatial Information.

A study conducted by Ardiansyah (2011) showed that in terms of the standardization of topographical names for natural elements, in particular, the name and number of islands in Indonesia, the island names standardization efforts must be done so that the de jure gains international recognition, of course, once deposited to the United Nations. Furthermore, it is said that the study has some problems, especially in terms of coordination between the authorities concerned, the number of tribes and local languages, as well as the limited funding. The number of islands that are uninhabited and yet to have a name complicate the naming standard. While on the other hand, the existence of Indonesia as an archipelago country with a definite number of islands needs to be deposited to the UN, so that international recognition can be obtained.

The result of a previous study on the provision of foreign names to the names of business entities, regions, and commercial buildings in the city of Surakarta showed that the use of foreign names, especially names in English, dominates as much as $80 \%$ and the rest use the combination of English and Indonesian and, or, Javanese language. This study emphasizes the structure and usage patterns of Indonesian (Kusumaningsih, 2013). Another study in the context of the Diklatpim III task (Nugroho, 2015) which takes the object of study in the city of Yogyakarta showed that many irregularities occur in the naming of topographic features of residential areas and buildings. However, this study is more focused on an institution's internal efforts, which in this case is D.I Yogyakarta Provincial Governance Bureau, in doing performance optimization in order for the orderly administration of the Governance Bureau.

The next study discusses the myth of foreign names in the naming of a residential complex in urban areas (Jilani, J, 2014). The study focused more on exclusive and prestige image for residents of urban dwellers and inhabitants which are grouped in classes and certain circles that are different from society in general. This study did not mention matters related to the provisions stipulated in the laws and regulations on the naming of the topographical elements.

Ismatul Khasanah et al., (2015) conducted a study on the naming of culinary business in Malang City in which the result concluded that the 
usage of Indonesia, slowly but sure, started to be overwhelmed by foreign strikes in its own fortress. The role of mass media actually can be expected to maintain and keep the existence of Indonesian usage.

The rise of the naming of regions and building in foreign languages since the last two decades is certainly contrasting the legislation in force and will greatly affect the existence of the use of the Indonesian language. All parties have a responsibility to keep preserving and using Indonesian in which Indonesian has been agreed as the unifying language. The position of the author is in the disagreement with the use of foreign languages in the provision of artificial elements of topographical names as this undermine the nationalist sentiment and pride to Indonesian.

This paper attempts to conduct a study on why many housing developers provide foreign language name to the name of man-made topographical elements, such as the name of housing/apartments and modern market. As for the background of this study, it is the tendency of a systematical naming of artificial elements in a foreign language and it is certainly destructive to the life of the nation due to the influence of globalization. What happens now to the use of Indonesian actually does not occur only in the topographical names of artificial elements, but has penetrated to the naming of other permits, such as permission in the hospitality business, theaters, and business management licensing of other meeting buildings. The factor of globalization is also used as a study material and the lack of socialization to the legislation becomes one of the causing factors. As is known, the Minister Regulation No 39 of 2008 on General Guidelines for Standardization of Topographic Names is a guideline used in the procedures and mechanisms for providing topographical names. In the regulation, there are eight principles that need to be shared. There are two principles that are directly related to the topic of this paper, namely (1) the principle of using local names and (2) the principle of the use of Indonesian and, or, local languages. The principle of using the local name is a form of respect in preserving the local name as the name is given to topographic features. The use of local names on behalf of housing area has been widely shared by the housing developers such as found in Table 1. It is necessary to appreciate the developer. The principle on the use of Indonesian and, or, local languages aims to honor the cultural diversity and national unity and integrity.

If we look deeper, a starting point of the naming of topographical with the principle of using local names and the use of Indonesian and, or, the local language, is a form of identity and entity of Indonesian people. This could definitely strengthen the integrity, unity, and solidarity of the nation in fortifying globalization and the influence of foreign culture is not good and does not match the personality of the Indonesian nation.

\section{METHOD}

The method used in this study is descriptive qualitative method. The object of the study is the names of housing, apartments, modern markets, and government office areas. The consideration on the selection of the object of this study on artificial elements is that the topographical names often do not regard the provisions of the applicable law regarding the naming of topographical. The study locations are in Bogor Regency and Bogor City with a consideration that there are many changes in land use into housing. The primary data are obtained from the office of the Integrated Licensing in Bogor Regency and Bogor City. Besides, also conducted interviews and consultations with structural officials from both the licensing office as well as interviews with some of the developers of housing and modern markets, a consultant in the field of licensing, and a direct observation by the author in residential areas, apartments, and modern markets in the regency and the city of Bogor. As for the secondary data, it is obtained from the study of literature and legislation relevant to this study. The information is also obtained from the consultation with the Public Relations Division of Indonesian Institute of Sciences (LIPI) about the history of the naming of Cibinong Science Center region.

In the Minister of Home Affairs Regulation No 39 of 2008 on General Guidelines for the Standardization of Topographic Names, mentioned that the topographic features are part of the earth's surface which identity is recognizable as the natural elements and man-made elements. The examples of natural elements are rivers, lakes, and mountains, while the examples of man-made elements are airports, office areas, dams, modern markets, and housing. Topographical names are the names given to each topographical element. In every topographical name, there are two elements of the name, generic name and specific name. Rivers, lakes, mountains, airports, dams and housing as the examples above are included in the category of generic names. While the specific names of the examples above are Musi (to the river), Toba (to the lake), Singgalang (to the mountain), SoekarnoHatta (to the airport), Jatiluhur (to the dam), Pasar Sarinah Jaya (to the modern market ) and Indraprasta (to the housing). The names of each of the topographical need to be standardized for the orderly administration and legal certainty, both in writing and pronunciation based on the rules and principles applied in the fields of toponymy science and the regulations apply. The standardization will be followed by the preparation of national gazetteer 
on all topographical names, both natural elements and artificial elements.

The definition of standardization is the process of determining the standard topographical names by competent authorities, both nationally and internationally. The process of determining and naming procedure is based on the topographic features of the Regulation No 39 of 2008 and the rules on toponymy science field.

In connection with the vocabulary of topographical names, there are other terms with the same meaning, i.e. toponyms, geographical names and place names. In the legislation, the vocabulary for place names, geographical names or toponyms is more popularly known, as topographic. At least there are two Laws which use topographical names for the designation of geographical names, namely Law No 24 of 2009 on the Flag, Language and Symbol of State, and Law No 4 of 2011 on Geospatial Information.

As mentioned, each topographical name, both derived from natural elements and man-made elements, need to be named and then standardized by the National Team. The team is chaired by the Minister of Home Affairs and composed of the Minister of Defence, the Minister of Foreign Affairs, the Minister of Maritime Affairs and Fisheries, and the Minister of National Education. For the technical implementation, the Minister of Home Affairs issued a decision to form the Implementation Team for the Standardization of Topographic Names, chaired by the Head of Bakosurtanal and consists representatives of members of the National Team. At the local level, there is the Committee for the Standardization of Topographic Names (PPNR) of Provincial level and PPNR of District level. The committee at the regional level is basically an arm of the National Team through the Executive Team and hierarchically the working relation is facilitative and coordinative.

When talking about standardization, principles, procedures and establishment of each of the topographical name, there are three important things that need to be stated. Those three things are the duty and the responsibility of PNR National Team.

1. Standardization. The standardization of topographical names aimed to (a) realize the orderly administration of naming topographic features in Indonesia, (b) ensure the orderly administration of the territory within the framework of the Republic of Indonesia, (c) realize the nationwide gazetteer so that there is a similar understanding of topographical names in Indonesia, (d) realize accurate data and information regarding topographical names in the whole region of Indonesia, for the national interest;
2. Principles. The naming principles of topographic elements includes (a) the use the Roman alphabet, (b) an element of topographical name for a name, (c) the use of local name, (d) referring to the legislation, (e) respecting the existence of ethnicity, religion, race, and groups, (f) avoiding the use of proper names and the names of people who are still alive, (g) using Indonesian and/or the local language, and (h) at most using three words to each of the topographical name;

3. Procedures and establishment. The inventory of topographic element names, both natural elements, and artificial elements, is started at the district level to all the elements that have been named as well as the elements that do not have a name. It must be noted on which topographical elements the priorities can be determined in advance by the user or the direction of the concerned District/ Municipality level PPNR. The inventory results of topographic features that have not been named and topographic features that have been named which are not in accordance with the principle of naming topographic then later, by the concerned Village/SubVillage Head, are proposed to sub-district after considering the proposed name from the society. Up to this stage, it is expected to have accumulated an inventory of topographic names for a district grouped by villages/subvillages. The next stage then is the inventory result of topographical names at the district level is submitted to the concerned Regency/ Municipality PPNR. The concerned Regency/ Municipality PPNR then conduct a review of the inventory result that has been done at the district level. The review is certainly conducted while involving the district. The result of the review at the regency/municipality level is then delivered by the Regency/Municipality PPNR to be forwarded to the Provincial Level PPNR for the National Team for the Standardization of Topographic name to then being verified again on the proposed standardization of topographic names.

Furthermore, the National Team, through the Executive Team for the Standardization of Topographic Names, standardizes the name, spelling, writing and pronunciation of topographic elements stored in a database form. The form of the topographical database is called national gazetteer. In the national gazetteer, collected all the topographical names, both the natural elements and the man-made elements. Sometimes a topographic name can have more than one name, but there is only one official name, while another name as the 


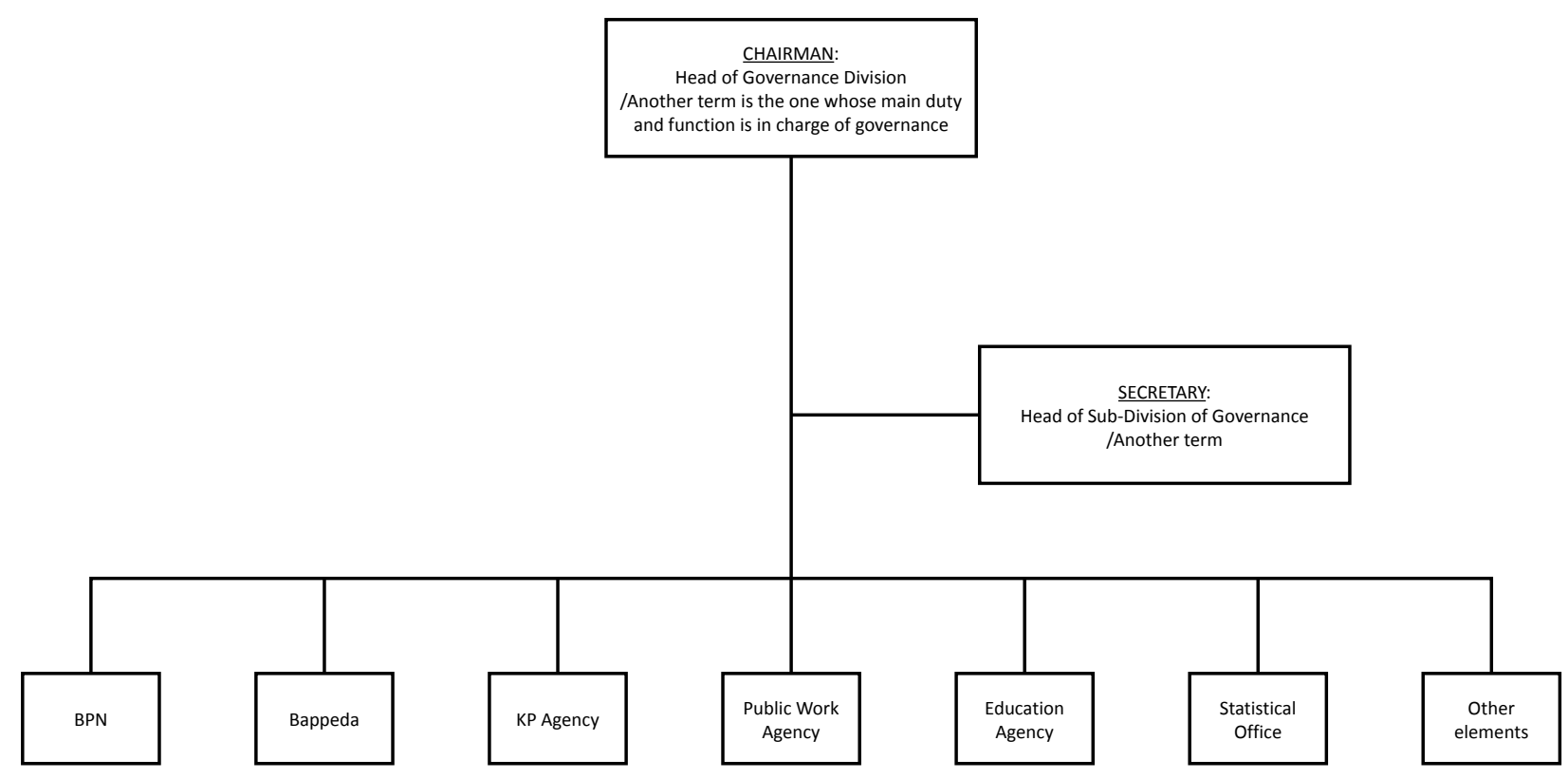

Figure 1. Organizational Structure of Regency/Municipality Level PPNR Source: PNR National Team, 2015

variant name. The standardization of topographic names is then set by a government regulation.

The existence of Regency/Municipality Level PPNR and Provincial Level PPNR is governed by the Minister of Home Affairs Regulation No. 35 of 2009 on the Guidelines for the Establishment of the Committee for the Standardization of Topographic Names. In the Regulation, stated that the Regent/ Mayor is responsible for the standardization activity of topographical names in the concerned regency/ municipality. To carry out these responsibilities, the Regent/ Mayor then formed Regency/Municipality PPNR. The tasks of Regency Level PPNR are (1) conducting an inventory of the name of topographic elements in the region (2) collecting and processing the data and information related to the name of topographic features (3) propose to the National Team the topographical names in their respective areas through Provincial level PPNR and (4) carrying out other tasks given by the National team and provincial level PPNR. The organizational structure for the Regency Level PPNR is described in Figure 1.

Furthermore, for the provincial level, the concerned Governor is responsible for the standardization of topographical names in the province and then form a provincial level PPNR. The generaldutiesofProvincialPPNRare(1) to coordinate and to verify the inventory of topographical names carried out by Regency/Municipality level PPNR (2) to propose topographical names to be standardized as national gazetteer preparation materials. The organizational structure for the provincial level PPNR is as Figure 2.

\section{RESULT AND DISCUSSION}

From the results of a study related to the use of the topographical name for artificial elements in foreign languages, especially English towards the names of housing provided by housing developers, at least can be categorized into three forms, namely (1) entirely in English, (2) a combination of Indonesian and English, and (3) a combination of foreign language and a term of a name in the form of acronym with special meaning. In terms of naming, the permission provision obtained from BPMTSP (Board of Investment and Integrated Services One Stop) of Bogor Regency and BPPTM (Integrated Licensing Service Agency and Investment) of Bogor City stated that the permission granted to the legal entity of the company or permit granted on behalf of the applicant. The naming of the housing is made separately after the location permit is obtained, as well as to the naming of modern markets.

It is to be seen in a modern market whether the name displayed on the building wall is the building name or the legal entity name in accordance with the name on IUPM (Modern Market Business License). If the name displayed is the name that matches the name on IUPM, hence the name, as stipulated in the licensing, should use the Indonesian language. Furthermore, if the name displayed is the name of the building, hence the name of the course should use the name in Indonesian. Matters related to the name as stated in IUPM still included in the study this paper. It's sometimes a bit difficult to distinguish whether the displayed name is the building name or the legal entity name. Based on the appendix of Trade Minister Regulation No 70/M-DAG/PER/12/2013 on Guidelines for Planning and Development of 


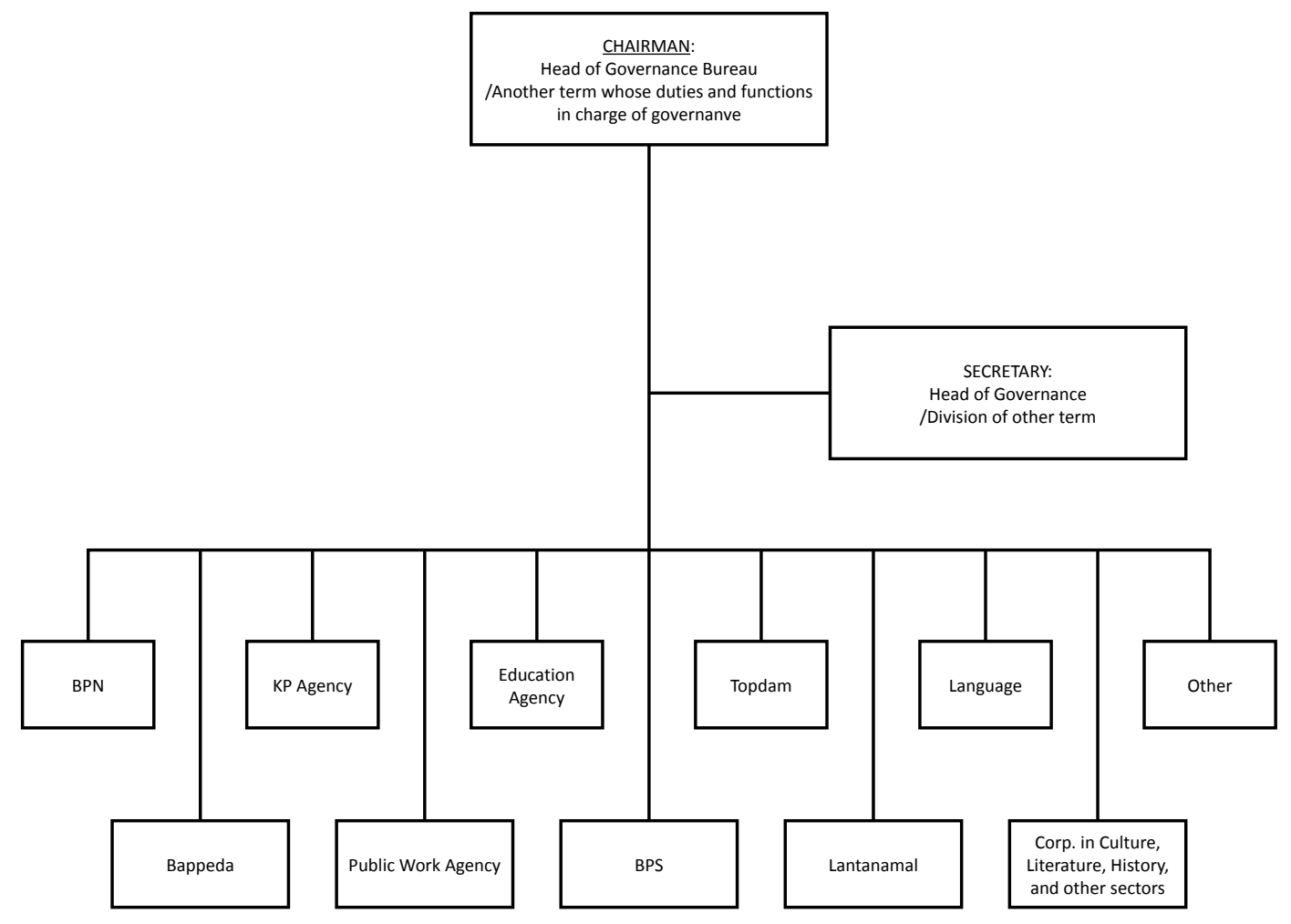

Figure 2. Organizational Structure of Provincial Level PPNR Source: PNR National Team, 2015

Traditional Markets, Shopping Centers, and Modern Stores, the license issued does not explicitly mention the name of the building where the concerned business is. The permit is granted to the company name or person in charge of the company, while the name of the business, whether in the form of mall/ trade center or department store/hypermarket/ grocery is determined on its own.

Article 36 of Law No 24 of 2009 does require the use of Indonesian in the geographical name (topographical names) and the geographical name has only one official name. So, how's the building that uses a foreign language? This problem must be communicated so that the facts that exist today do not cause turmoil in society. The fundamental issue that is important does not let the legislation that already exists only to the extent that we have to have rules, while on the other hand, the violation committed against the legislation persists. Unfortunately, in Law No 24 is not found sanction against violation, despite a word "mandatory". The mandatory word should imply mandatory and should be implemented. The absence of legal sanctions for anyone who does not comply with the obligation on the provision of a geographical name as mandated by Article 36 of Law 24 of 2009 does not mean an obligation to use Indonesian on geographical names can be ignored. An obedience to the mandate of the law in effect cannot be seen with whether there is a sanction or not. Here, the authority of the law needs to be maintained and all parties must respect the law.

The Minister of Home Affairs Regulation No 39 of 2008 has provided an affirmation that the naming of the topographical elements must use Indonesian and/or local languages. The use of local languages aims to maintain the existence of local languages and things that are historical towards the naming remains preserved. In the provision of artificial elements, topographical names must be based on both law regulations.

If seen from the facts that occurred, so many residential areas built by developers of housing (property developers) and modern market entrepreneurs, giving names in foreign languages, especially English. Some of the reasons given by managers of housing developers to the administration part of the name in English or in combination with Indonesian is that this is more to the trend of the growing use of foreign names in the community today. The use of foreign names for housing name is a marketing strategy undertaken by the developer so that the selling value of such housing could be higher. The reason for marketing strategy taken into consideration on the provision of topographical names is actually just in terms of the benefits that can be scooped by the developer.

Another factor that becomes the cause is that not all parties have understood the legislation regarding the obligation to use Indonesian in the 
Table 1.

The Provision of Artificial Elements Topographical Names in the Regency and the City of Bogor

\begin{tabular}{ccc} 
Fully English & $\begin{array}{c}\text { Combination } \\
\text { of English } \\
\text { and Indonesian }\end{array}$ & Fully Indonesian \\
\hline 5 & 27 & 8 \\
\hline
\end{tabular}

naming of the topographical elements. On the license issued, it does not explicitly list the name of the object of topographical names but includes the name of individuals or legal entities who filed for the permit. In addition, the requirements that must be completed in the licensing does not require to put the building name or the name of a residential neighborhood. The absence of legal sanction in the legislation on the obligation to use the name of the topographical elements as stated in paragraph (3) of Law No 24 of 2009, resulting in the parties freely use the name of the topographical elements arbitrarily. A globalization factor also leads to a shift towards cultural values and the use of Indonesian in social life. The globalization meant here is the interaction, communication, and information from around the world that are happening and can be obtained quickly and easily through information technology and mass media. Some factors trigger a shift in the use of Indonesian in the naming of topographical artificial elements are: (1). Advances in the field of information technology. The progress in the field of information technology that is rapid and fast facilitates the dissemination of information from one country to another. The spread of information coming from the various aspects of social life can be negative or positive. (2). Ease of migration. The existence of multiple interests and objectives, human move easily and mingle from one country to another to bring the values of the culture and customs of each. (3). The economy and trade. Aspects of the economy and trade also resulted in a shift in cultural values and customs.

All those triggering factors need to be eliminated and it is the commitment of us all to make the Indonesian language as the unifying language of the nation. The sense of nationalism to the use of Indonesian should be a concern of all parties and it is necessary to immediately declare by the government

The results of the study of topographical names for residentials/apartments and modern markets in the Regency and the City of Bogor is showed in Table 1.

From the 38 artificial elements topographical names found, there are 8 residentials that fully utilizes Indonesian. It is quite alarming to the awareness of the use of Indonesian in the naming of topographical artificial elements. What is interesting
Table 2.

Overview of Decree Form

\begin{tabular}{cll} 
Stipulated & Name & $\begin{array}{c}\text { Providing the Permits } \\
\text { of Land Use Utilization to: }\end{array}$ \\
& $:$ & $\begin{array}{l}\text { (individual name } \\
\text { or legal entity name) }\end{array}$ \\
\hline To & $:$ & Residential Development \\
\hline Location & $:$ & $\begin{array}{l}\text { (area is stated in unit of meter } \\
\text { per square) }\end{array}$ \\
\hline & $\begin{array}{l}\text { (stated comprehensively the } \\
\text { Neighbourhood/Community, } \\
\text { Sub-Village, District, City/ } \\
\text { Regency) }\end{array}$ \\
\hline
\end{tabular}

Source: BPPTM of Bogor City, 2016

is that the majority of the development of residentials and modern markets give topographical names in Indonesian and English. Only 5 topographical names that are entirely in English. Although the majority of developers use a combination of names between Indonesian and English, this nevertheless violates the legislation provisions in force.

Below stated some notes that need to be delivered from the data analysis, as follows:

\section{Residential Area Location Permits}

Location permit is a form of government approvals granted to housing developers for building a residential area. Location permit granted in the form of Decree of the Head of BPPTM (SK), of course, after considering all the specified requirements. Table 2 provides an overview of the content on residential areas permit issuance.

In the permit, mentioned several requirements that must be met at the time of construction of housing, among other things is the obligation of managing the environment, managing drainage system, adjustment to technical provision of Basic Building Coefficient (KDB), provision of green open space (RTH), provision of public facilities and infrastructure, provision of street lighting (PJU). The naming of the residential area is fully given by the developer company or individual owner.

\section{Building Permit (IMB) of Building}

The permit for a modern market and an apartment building is also issued in the form of Decree (SK). In the decree, included the permission to the applicant, could be a legal entity or individual to construct a building. In the decree, there is an attachment that describes things related to the technical building construction and the allotment of the building. In the decree, not mentioned the name of the modern market and the apartment building. The name of the building is provided by 


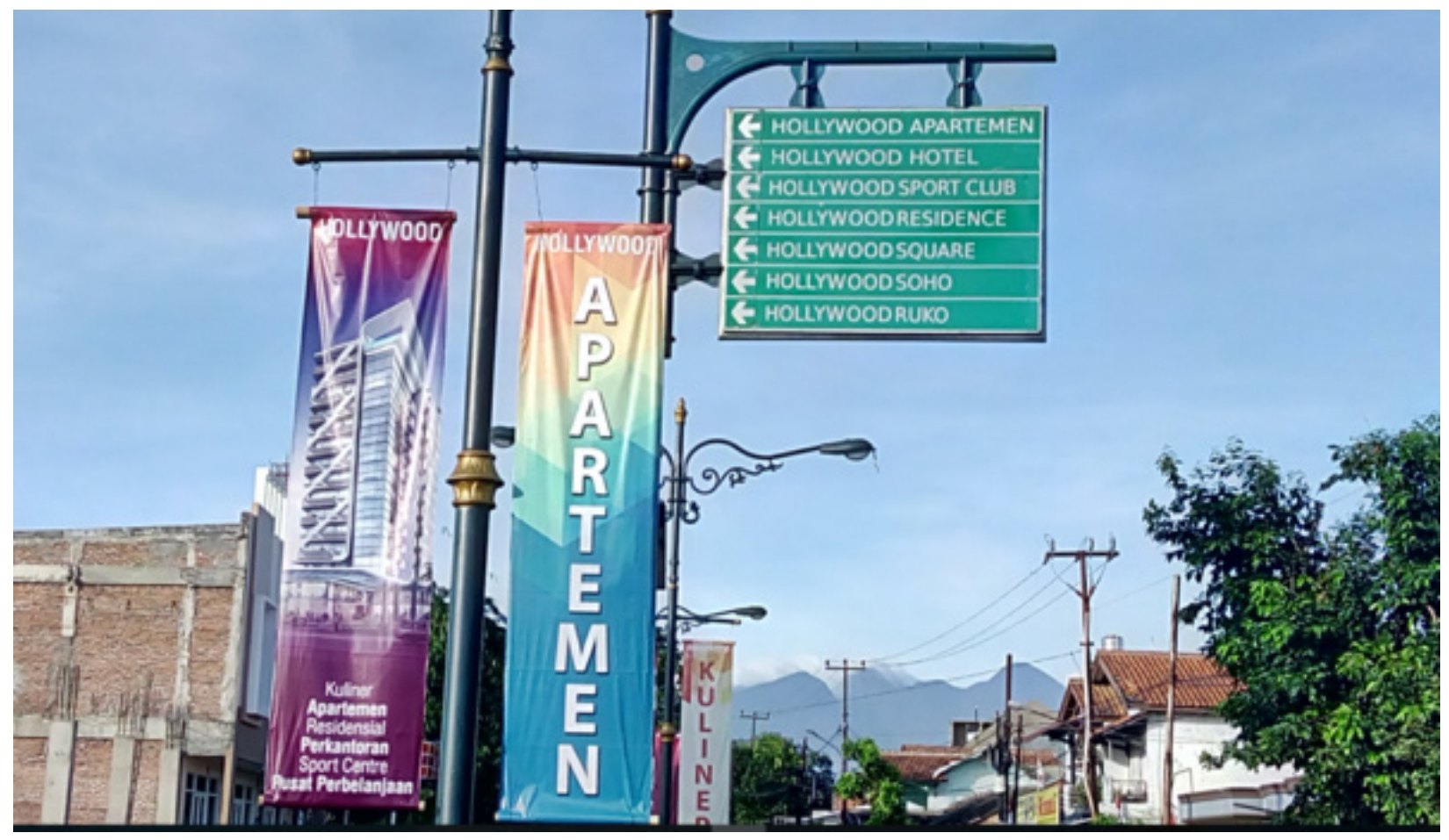

Figure 3. Name of Residential/Apartment with Foreign Name Photo: Asadi, 2016

the applicant, both for the modern market name or the apartment name.

\section{Cibinong Science Center}

It is interesting to say in this article about the naming of an office area that has been presented in Table 1 above. The office area of government agencies (LIPI and BIG) which are now named Cibinong Science Center Botanical Garden, for the first time decided by the Sukarno government in the early 1960s (PR of LIPI, personal communication 2016). The construction began with laying the first stone by President Sukarno in 1964 and was named Life Science Center (LSC). On the basis of the concept in 1964, then by the Head of LIPI, issued Decree No 01/A/2002 on the establishment of Authority Agency of Cibinong Science Center (CSC), which later, under the Head of LIPI No 1219/A/2014 became the Management Agency of Cibinong Science Center and Botanical Garden (CSC-BG).

Of naming using the English language that has been declared by the Government of Sukarno with LSC name, it certainly does not correspond to the spirit of the use of Indonesian in giving the names of topographic elements. Indeed, at the time of the declaration of the name of the region, the Law No 24 of 2009 has not been issued, let alone the Minister of Home Affairs Regulation No 39 of 2008. So, can it be said that the naming of the government office area completely violates the existing provision? of course, this naming is debatable! That the naming of regional government offices to use the English language, either by the President followed by the decision of the Head of LIPI, must have a specific reason. If we are talking in the context of science, certainly not just limited to science at the national level, this is already an international concern. The problem is, how to address if there are provisions that require the use of Indonesian in the provision of topographical names as the legislation mentioned above.

The area name of CSC-BG could be maintained, but on the nameplate or in the letterhead, needed to consider giving the name of the region in Indonesian, and the name in the Indonesian language is its formal name, while the name in English is its international name. On the nameplate of the region, included both formal names and international name, whereas formal name is written in advance with a larger font size than the international name.

Referring to the Presidential Regulation No 112 of 2006 on the National Team for the Standardization of Topographical Name, it is mentioned that this team has the task, one of which is nationally standardizing name, spelling, and phonetic of the topographical elements in Indonesia in the form of the national gazetteer. This Presidential Regulation is a followup to the UN Resolution of 1967 which asks each country to have such "national name authority". Through this institution, matters concerning the naming, spelling, speech, formal writing to standard topographical names, assigned, then the names that have been mentioned subsequently deposited into the United Nations. One of the tasks that in 


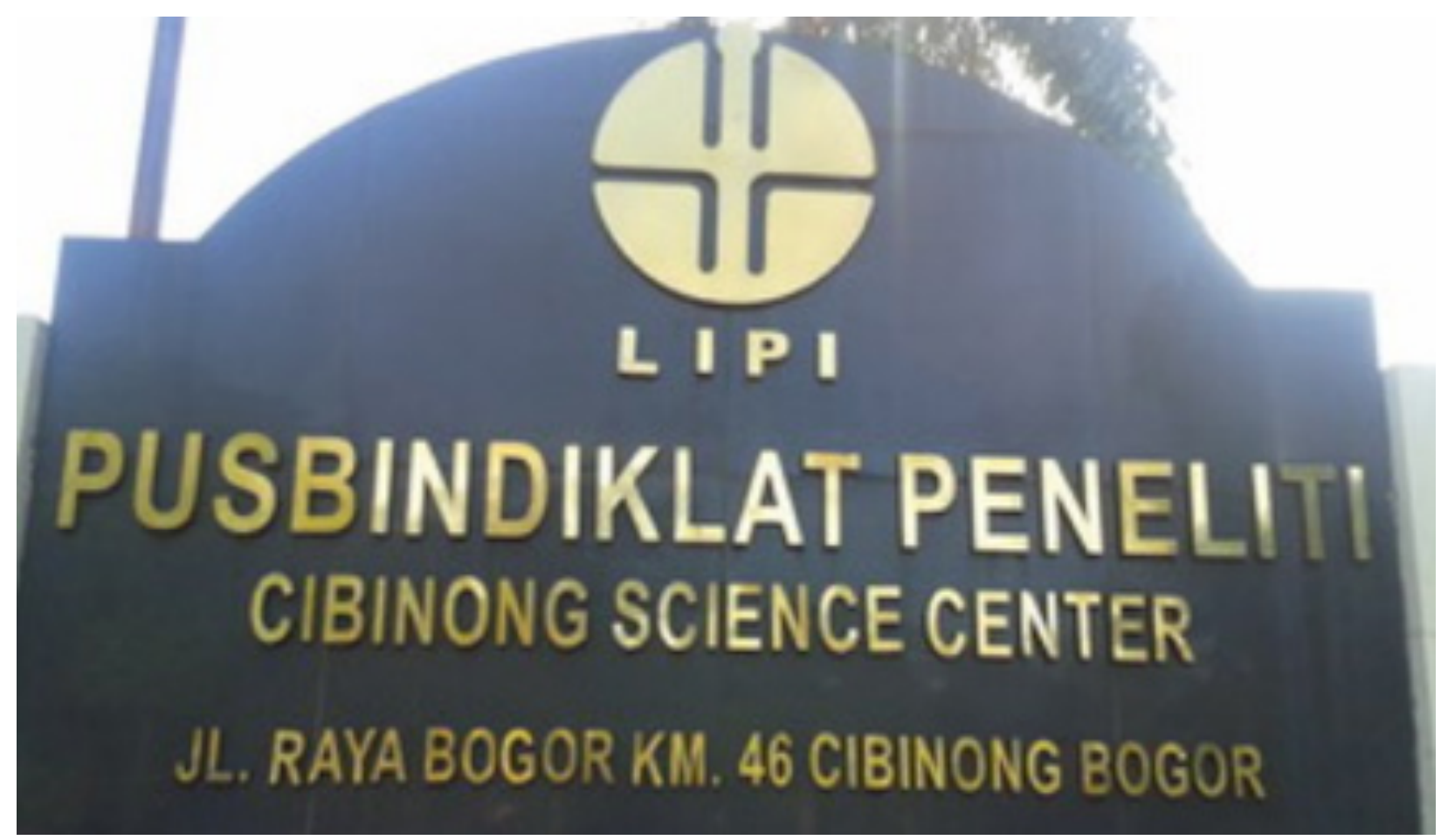

Figure 4. Office Area of CSC-BG LIPI-BIG, Cibinong Source: http://uun-halimah.blogspot.co.id/2013

a few years we have heard is to deposit the name and number of islands in Indonesia to the United Nations through the United Nations Groups of Experts on Geographical Names (UNGEGN), which now records as many as 13.466 islands. The islands inventory number seems to be unfinished and will still be continued in the coming years.

In carrying out the task of the standardization of name, spelling, and pronunciation, it is backed by rules and conditions as stipulated by the Minister of Home Affairs Regulation No 39 of 2008 as mentioned earlier. The existence of the National Team and Provincial and Regency/Municipality PPNR is deemed to have a strategic position in helping the naming of topographical elements in accordance with the existing regulations. Under the plan that has been prepared, the National Team for the Standardization of Topographical Name now has declared to carry out an inventory of manmade elements name. The Guideline of Artificial Elements Naming has been discussed and just needs to be published and disseminated by the National Team for the Standardization of Topographical Name. As mentioned, there are many man-made elements that need to be inventoried. Some examples of topographical artificial elements are the name of the building, the name of the housing, the name of the apartment, and the name of the market, including the name of the modern market. The whole artificial topographical names will be standardized and subsequently made in the form of database (gazetteer) and in the end still needs to be deposited to the United Nations, just like the names of the island.

One solution to the issues related to the obligation to use Indonesian in the naming of topographical elements is the re-socialization of the legislation related to the naming of the topographical elements. For the names that are already in foreign languages, the vocabulary will be changed into Indonesian dialect or change the foreign word into Indonesian. This change will certainly have an impact on many things, among others, to the address on the ID card (Identity Card) of a person, and the address listed on the ID card will have an impact again on the administrative documents of the bank, along with other documents. It certainly would be easier if there is a political decision of the government. Another solution that can be considered is a foreign name to be the additional name which writing is made smaller than the main name where the main name used is the name in Indonesian.

Another thing that can be considered, and this becomes a thought to be shared is to conduct a revision of the legislation related to the use of Indonesian for topographical names. The provision of topographical names on man-made elements as mandated in Article 36 paragraph (1) of Law No 24 of 2009 which does not sanction must be amended so that all parties concerned can obey and the state can take steps so that there is no violation of law. The existence of Indonesian in the naming of topographical elements is one of the fundamental things so that the unity of the Republic of Indonesia 


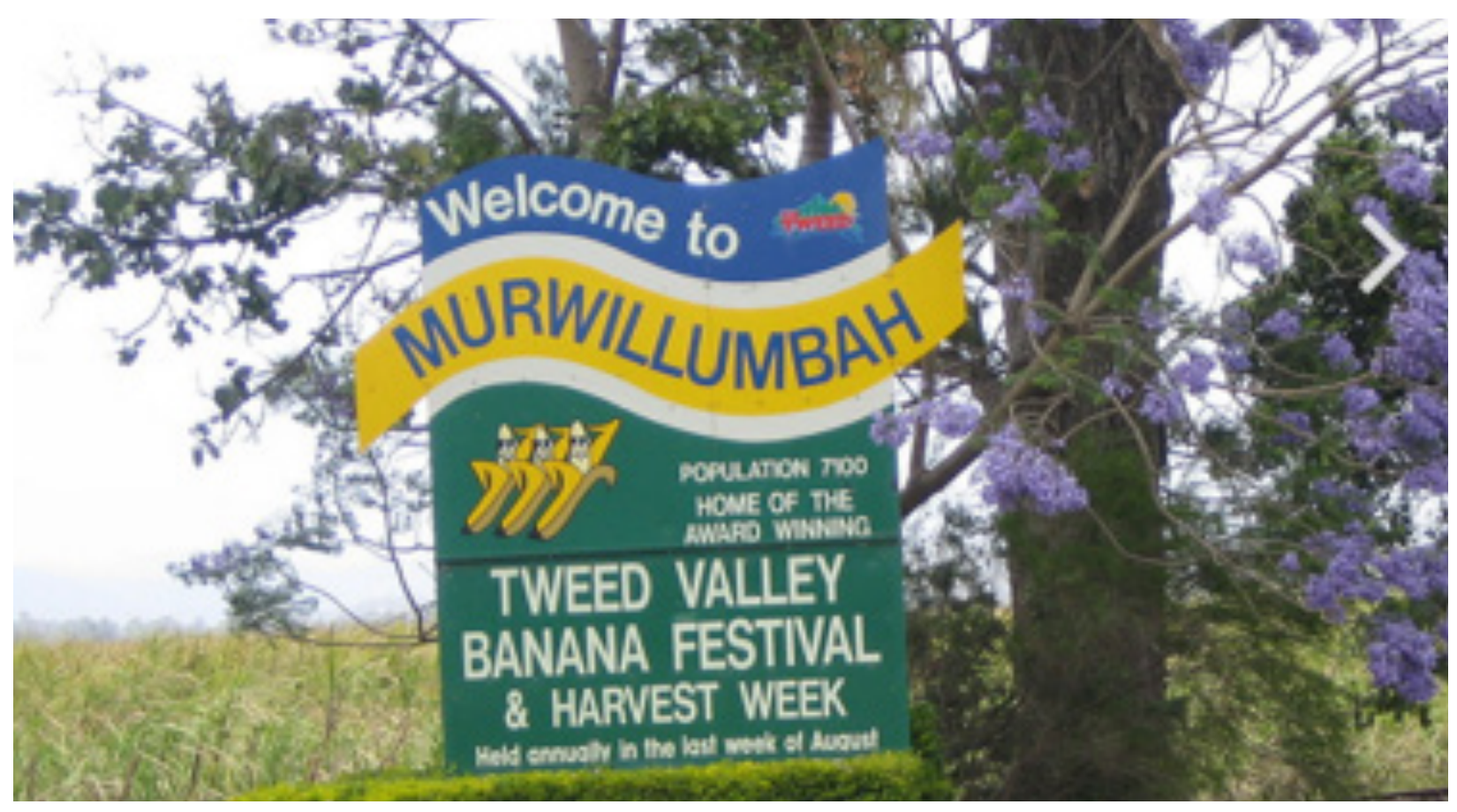

Figure 5. The Name of Murwillumbah is originated from Bandjalang language, one of the native languages of Aborigin, Australia Source: https://en.wikipedia.org/wiki/List_of_Australian_place_names_of_Aboriginal_origin

can be maintained. We may not have thought to do the revolutionary movement in enforcing the use of Indonesian as did the Government of China in blocking the effects of globalization, as mentioned earlier in this article. At least all parties must be aware and try to make the Indonesian language as a means of unifying, love the Indonesian as a language that can be proud of and uphold the spirit of the Youth Pledge in 1928.

\section{Conclusion}

The naming of man-made topographical elements, especially for the name of residential, apartment, and modern market areas that are implemented by the developer and entrepreneurs, is generally given after obtaining permission from the relevant authorities on the type of business. The naming given, especially on behalf of residential, has a tendency to use foreign names, especially names in English. There are at least four reasons why foreign names are used in the naming of the topographical artificial elements, that is the factor of globalization, marketing strategy, and the yet disseminated legislation, as well as no sanctions for violations. Globalization factor can not be denied to be one of the causes of the artificial topographical element names usage. The names of residential/ apartment and the name of a modern market which have been mentioned above can be the evidence of the influence of globalization in pervading our society. In the marketing strategy, it adds value when topographical names given to residential/ apartment and modern market areas use foreign names, especially names in English. Related to the yet disseminated legislation to all parties, it becomes an obstacle to the creation of consistency in the use of the Indonesian language. This is compounded by the absence of sanctions for violations of the provision of artificial element topographical names.

In order for the condition to be restored, then there must be real steps initiated by the government to declare the use of Indonesian, especially in the provision of artificial element topographical name. After going through the declaration and dissemination on the use of Indonesian in the naming of the topographical name, then the government institution issuing the Permits Building License (IMB), in the IMB must state the topographical name of the concerned building. Similarly to the location permits for residential, must have stated the name of the residential on the permits. After everything is understood and socialized well to the society and the government apparatus, then the imposition of the sanction, either as a crime or fine towards the violation of the provision of topographical element names can be done by first performed changes on the law regulation related to the naming of topographical elements.

One important thing that must be put into consideration, especially for the National Team for the Standardization of Topographical Name and the Language Development And Fostering Agency, to necessarily together start a campaign so that all parties, Cental Government, local governments, private sector, and the society to use Indonesian and/or local languages for the provision of artificial 
elements names. It must be conditioned that using Indonesian is a pride. The perception that the use of foreign languages in the provision of residentials, apartments, and modern markets will increase a business opportunity must be eliminated.

As a closing of this paper, the author would like to inform that in Australia, for example, the names of the native aborigines are still maintained as the names of residential areas as shown in Figure 5. It seems that we need to eliminate the inferiority of using any local language name for the name of a luxury housing. The name of houses or apartments using foreign names does not necessarily make the houses or apartments' level of eliteness increased. This condition is actually merely a perception.

\section{ACKNOWLEDGEMENT}

Taking this opportunity, the author would like to thank Mr. Denny Mulyadi, S.E. as the Head of Integrated Licensing Service and Capital Investment (BPPTM) of Bogor City as well as his apparatus who have provided the data and the information and the consultation related to the provision of licensing data issued to the developer of housing, apartment, and modern market in Bogor City. The gratitude is also expressed to Mr. Irawadi, S.E. as the Head of Sub-Division of Data and Information to the BPPTM of Bogor Regency who has provided the data and information related to the licensing of housing and modern market in Bogor Regency area. The gratitude is also expressed by the author to the PR of LIPI who has given the information related to the history of the naming of Cibinong Science Center. The author also would like to thank the colleagues at the Training Hall of BIG Geospatial, especially to Ir. Soma Trenggana, M.AppSc. who has sincerely providing a moral encouragement in the writing of this paper. Hopefully all the assistance given will be of good deeds and gain favorable return from Allah 'azza wajalla. Amen.

\section{REFERENCES}

Agustan. (2008, July). Toponimi, Bukan Hanya Tata Cara Penulisan Nama Unsur Geografis. Majalah INOVASI, 11, 91-94.

Ardiansyah, A. (2011). Pembakuan Nama Pulau di Indonesia Sebagai Upaya untuk Menjaga Kedaulatan Negara Republik Indonesia. Pandecta, 6(1), 117-127. Retrieved from http:// journal.unnes.ac.id/artikel_nju/pandecta/2330

Arifin, E. Z. (1991). Seribu Satu Kesalahan Berbahasa. Jakarta: Akademika Pressindo.

Asadi. (2015). Nama Rupabumi, Toponim, Aturan dan Kenyataan. Jurnal Lingkar Widyaiswara, 2(4), 18-35. Retrieved from http://juliwi.com/ published/E0204/Juliwi0204_18-35.pdf
Candrawinata, I. (2014). Penggunaan Bahasa pada Papan Nama Toko di Malioboro. Universitas Negeri Yogyakarta. Retrieved from http:// eprints.uny.ac.id/17938/

Fleury, C., \& Raoulx, B. (2016). Toponymy, Taxonomy and Place. Shima: The International Journal of Research into Island Cultures, 10(1), 8-20. http://doi.org/10.21463/shima.10.1.04

Hadibrata, H. (2015). Bahasa Indonesia dari Bahasa Melayu menuju Bahasa Dunia. In Seminar dan Lokakarya Kebahasaan Lembaga Adat.

Halim, Y. (1989). Memantau Toponimi dan Permasalahannya di Indonesia. Majalah Geografi Indonesia, 2(3), 11-18. http://doi.org/10.22146/ mgi,5278

Hutagalung, R. (2012). Bahasa Indonesia yang Terjajah di Negeri Sendiri. Retrieved June 18, 2016, from http://www.kompasiana.com/rihat/bahasa-indonesia-yang-terjajah-di-negeri-sendiri_55125c59a33311bd56ba83ab

Jaelani, J., Sulistianingtyas, T., \& Jatnika, A. W. (2014). Mitos Nama Asing di dalam Penamaan Kompleks Perumahan di Wilayah Perkotaan. Jurnal Sosioteknologi Institut Teknologi Bandung, 13(3), 239-249. Retrieved from http:// journals.itb.ac.id/index.php/sostek/article/ view/1153

Karsidi, A. (2013). Peran Toponimi dalam Pelestarian Budaya Bangsa dan Pembangunan Nasional. In Seminar Nasional Toponimi. Bandung.

Khasanah, I., Laksmita, D., Tilman, R. D. C., \& Rizki, R. (2015). Fenomena Penggunaan Bahasa Asing dalam Penamaan Bisnis Kuliner di Kawasan Soekarno Hatta Kota Malang. Jurnal Lingkar Widyaiswara, 2(1), 1-11. Retrieved from http://juliwi.com/published/E0201/Paper0201_01-11.pdf

Kusumaningsih, D., Sudiatmi, T., \& Muryati, S. (2013). Pengindonesiaan Kata dan Ungkapan Asing pada Nama Badan Usaha, Kawasan, dan Gedung. Jurnal Pendidikan, 22(3), 267-276.

Lauder, M. R. M. T. (2013). Peran Toponimi dalam Pelestarian Budaya dan Pembentukan Jati Diri Bangsa. In Seminar Nasional Toponimi. Bandung.

Nugroho, T. (2015). Laporan Implementasi Proyek Perubahan Diklat Kepemimpinan III. Yogyakarta.

Perdana, A. P. (2013). Pembakuan Nama Rupabumi sebagai Bagian Geostrategis NKRI. In Prosiding Pertemuan Ilmiah Tahunan XVI Ikatan Geograf Indonesia (pp. 675-685). Banjamasin: Ikatan Geograf Indonesia. http://doi. org/10.13140/2.1.1536.9607

Public Relation of LIPI. (2016). Communication through Email.

Pusat Bahasa Departemen Pendidikan Nasional. (2003). Pengindonesiaan Kata dan Ungkapan 
Asing. Jakarta: Pusat Bahasa.

Rais, J. (2008). Toponimi Indonesia (1st ed.). Jakarta: Pradnya Paramita.

Republic of Indonesia. (2012). National Report of Tenth United Nations Conference on the Standardization of Geographical Names. New York.

Rose-Redwood, R. (2011). Rethinking the Agenda of Political Toponymy. ACME: An International E-Journal for Critical Geographies, 10(1), 3441. Retrieved from https://ojs.unbc.ca/index. php/acme/article/view/884/740

Samosir, H. A. (2016). China Berencana Ganti Nama Perumahan Berbahasa Asing. Retrieved June 18, 2016, from http://www.cnnindonesia.com/internasional/20160323160854-113-119323/ china-berencana-ganti-nama-perumahan-berbahasa-asing/

Subowo, E. (2013). Kebijakan Nasional Pembakuan Nama Rupabumi. In Seminar Nasional Toponimi. Bandung.

Sugono, D. (2015). Peran Bahasa Indonesia sebagai Alat Pemersatu dalam Negara Kesatuan Republik Indonesia. In Prosiding Seminar $\mathrm{Na}$ sional Bulan Bahasa 2015 (pp. 1-14). Bengkulu: Unit Penerbitan FKIP Universitas Bengkulu. Retrieved from http://repository.unib. ac.id/11107/

Sugono, D. (2015). Pedoman Teknik Inventarisasi dan Verifikasi Nama Rupabumi Unsur Buatan. Tim Nasional Pembakuan Nama Rupabumi.

Tichelaar, T. (2002). Toponymy and Language. Frankfurt: DGSD-UNGEGN.

China Hapus Nama Asing di Kompleks Perumahan. (2016). Retrieved June 18, 2016, from http:// dunia.inilah.com/read/detail/2282996/china-hapus-nama-asing-di-kompleks-perumahan

Indonesian Presidential Regulation No 112 of 2007 on Planning and Development of Traditional Markets, Shopping Centers and Modern Stores, Pub. L. No. 112 (2007).

Ministry of Home Affairs Regulation No 39 of 2008 on Guidelines for Standardization of Topographical Names, Pub. L. No. 39 (2008).

Trade Minister Regulation No 70/M-DAG/ PER/12/2013 on Guidelines for Planning and Development of Traditional Markets, Shopping Centers, and Modern Stores, Pub. L. No. 70/M-DAG/PER/12/2013 (2013).

Law No 24 of 2009 on the Flag, Language, and Symbol of State, as well as Anthem, Pub. L. No. 24 (2009). Indonesia. 